\title{
Acephate bait for eliminating honey bee swarms in swarm traps *
}

\author{
JL Williams, JD Villa, RG Danka \\ USDA, ARS, Honey-Bee Breeding, Genetics and Physiology Laboratory, \\ 1157 Ben Hur Road, Baton Rouge, LA 70820, USA
}

(Received 18 May 1992; accepted 31 August 1992)

\begin{abstract}
Summary - Field experiments were conducted to assess the effects of acephate-treated (Orthene ${ }^{\circledR} 75 \mathrm{~S}$ ) sucrose bait and bait packaging methods on artificial honey bee (European-derived stock) swarms in swarm traps. Consumption of acephate bait by swarms and bee mortality depended upon acephate concentration and packaging material. Of 2 types of packages and 10 acephate concentrations tested, 450,500,1500 and $4500 \mathrm{ppm}$ acephate bait in wax paper envelopes eliminated swarms and most queens within $1 \mathrm{~d}$. Detectable worker mortality in traps ranged from $18 \%$ (150 ppm, cup) to $73 \%$ (4500 ppm, envelope) of original populations of ca 12000 bees. The toxic bait has potential as an economical and safe technique for destroying swarms captured during Africanized honey bee survey and abatement programs.
\end{abstract}

Apis mellifera / Africanized honey bee / acephate bait / swarm trap

\section{INTRODUCTION}

Abatement technology for localized feral Africanized honey bee (AHB) populations will be particularly useful to protect visitors and employees of major high-use outdoor facilities (eg public and theme parks, zoos, resorts, school campuses, sports stadiums and government building complexes) from potentially serious stinging encounters. Technology for minimizing in- teraction between $\mathrm{AHB}$ and the public will help to reduce adverse publicity concerning nuisance honey bee situations and, in turn, will benefit beekeeping and the production of bee-pollinated crops by helping to prevent unnecessary regulations governing transport of managed bee colonies.

Swarm traps of various types have been used extensively in Mexico to detect and monitor feral AHB populations (Rubink et al, 1990) and are presently de-

" This paper reports the results of research only. Mention of a proprietary product does not constitute an endorsement or recommendation by the US Department of Agriculture for its use, nor does it imply registration under FIFRA as amended. 
ployed in Texas to detect AHB swarms and for ecological studies. Application of swarm traps to control localized AHB populations was proposed earlier on theoretical grounds (Gary, 1971; Michener, 1975; Witherell and Lewis, 1986). Subsequently, high swarm capture rates were realized using beeswax and pheromone-baited cardboard hives against AHB populations in Mexico (Fierro et al, 1988) and Nasanov pheromone-baited wood pulp hives in areas of the southwestern US with European honey bees (Schmidt and Thoenes, 1987, 1990; Schmidt et al, 1989). In 1991, ca 1000 swarm traps were deployed in the AHB survey and research programs in Texas. Over the next few years, the use of swarm traps will increase markedly as the range of $\mathrm{AHB}$ expands into other southern states.

The use of a toxic bait to destroy newly collected swarms can minimize the risk of serious stinging events for trap operators and others nearby (Witherell and Lewis, 1986). Eliminating swarms soon after they enter swarm traps prevents the transition of such mobile populations from a survival, typically nondefensive behavioral mode into stationary, broodrearing colonies which are nest defensive. Such a system can also economize survey and abatement program workloads by reducing the frequency of bait hive inspections required to prevent rapid population increase and subsequent absconding and swarming of colonies attracted to bait hives during the reproductive season. An acceptable toxicant system must be effective, it must rapidly destroy captured swarms without causing a stinging hazard from intoxicated bees, and it must pose little or no hazard to nontarget organisms.

Small amounts of acephate are known to acutely destroy colonies when presented as a sucrose-honey bait from distances of 5-1 $000 \mathrm{~m}$ or to cause chronic lethal in- toxication when fed directly to colonies as treated sucrose syrup (Stoner et al, 1985; Williams et al, 1989; Danka et al, 1992). Sucrose-honey fondant (similar to queen candy) was chosen instead of sucrosehoney syrup as the toxicant carrier for the present study because a drier preparation is less attractive to nontarget insects and other animals, and it is easier to handle and store. The baits were packaged for protection against weather, nontarget scout honey bees, and other small nontarget animals.

\section{MATERIALS AND METHODS}

Field tests were conducted in 1990 and 1991 on the Idlewild Station of the Louisiana Agricultural Experiment Station, near Clinton, LA, USA. The station covers ca 1750 acres in a poor beekeeping area (Oertel, 1971) and is isolated from managed bee colonies.

The response of hived artificial swarms to packets of sucrose-based bait containing different concentrations of acephate was observed for $10 \mathrm{~d}$ each year. Artificial swarms were $1.4-\mathrm{kg}$ (3-lb) packages of European-derived stocks of bees held overnight in a cool room ( $\mathrm{ca} 20^{\circ} \mathrm{C}$ ) and installed in swarm traps the following day. Bait hives were 31-I pressed wood pulp bee pots (Western Pulp Products Co \# D1-29, Corvallis, OR 97339) (Schmidt et al, 1989), which have tight fitting lids and a $2.5-\mathrm{cm}$ diameter hole in the bottom. The package bees were sprinkled with dilute sucrose solution ( $3: 1$, water: sucrose) at installation to inhibit general activity and absconding. A caged queen was suspended from the inside top center of the bait hive before package bees were added. Each bait hive was then placed on a wood stake or tree limb ca 1-1.5 $\mathrm{m}$ above ground. Bait hives were located along a lane through a forested area.

\section{Test 1}

Toxic effects of acephate $(0,150,300$ and 450 ppm) baits packaged in 2 different ways ( 8 treat- 
ments) were evaluated against stimulated swarms of bees. Bait was prepared $24 \mathrm{~h}$ prior to use with confectioners' sugar $(70.2 \%)$, heated honey $\left(21.6 \%\right.$, ca $\left.60^{\circ} \mathrm{C}\right)$ and required amounts of acephate (Orthene ${ }^{\circledR} 75 \mathrm{~S}$ ) dissolved in water $(8.2 \%)$; all were mixed thoroughly by hand. The finished bait was stiffened by cooling at ca $5{ }^{\circ} \mathrm{C}$ to aid handling. Baits were held at $5{ }^{\circ} \mathrm{C}$ until used. Control baits were prepared similarly, but with increased amounts of confectioners' sugar.

The 2 types of packaging for the baits consisted of (1) wax paper (Reynolds ${ }^{\circledR}$ Cut-Rite) envelopes (12 $\mathrm{cm} \mathrm{H} \times 14 \mathrm{~cm} \mathrm{~L}$ ) and (2) covered wax paper cups (Lily \#450, $95 \mathrm{ml}$ ). The envelopes were sealed on the sides and top with cellophane tape; paper cups were covered with household wax paper folded over the lip of the cup and secured with a rubber band. Packages of bees $(56 ; n=8 /$ treatment, except $4 /$ treatment in 2 controls) shaken on the 27 June were given caged queens, held overnight (as above) and then installed in bait hives on the next day. On 29 June, each queen was released and a bait was suspended where the queen cage had been. Each bait hive received $20 \mathrm{~g}$ of bait in 1 envelope or 1 package. However, to approximately equalize total doses, hives of the 2 groups given $150 \mathrm{ppm}$ bait were each given a $30 \mathrm{~g}$-package. Daily inspections were made until colonies with acephate bait died (population with no queen and $<500$ live workers). Observations included bait consumption, general colony behavior (including position of swarm cluster), presence of a live or dead queen, worker mortality (direct counts or derived by weight) and nontarget insects feeding on bait or dead bees.

\section{Test 2}

Toxic effects of $0,500,1500$ and 4500 ppm acephate bait on artificial swarms (32; $n=8 /$ treatment) in bait hives were evaluated in 1991. Wax paper envelopes (as in test 1) each containing $25 \mathrm{~g}$ of bait were used in all treatments. Packages of bees were shaken on 21 May 1991, treated on 23 May and then monitored for $10 \mathrm{~d}$. Acephate consumption and worker mortality data from both tests were analyzed by analysis of variance (SAS, 1985) to distinguish differences between effects of packaging methods (test 1) and acephate concentrations (test 1 and 2).

\section{RESULTS AND DISCUSSION}

\section{Test 1}

Colonies given acephate bait in envelopes consumed more acephate as concentration increased; colonies given cups showed much less clear consumption trends (table I); the interaction between packaging method and concentration was significant $(F=3.85 ; d f=2,41 ; P=0.029)$ (table I). Colonies chewed through wax paper cups and covers less actively than through wax paper envelopes, and dead bees accumulated on the bait in cups, causing irregular mortality and decreased efficacy. Envelopes containing $450 \mathrm{ppm}$ bait comprised the most efficacious treatment in test 1 ; swarms so exposed consumed the most acephate $(6.6 \pm 0.9 \mathrm{mg}, \bar{x} \pm S E)$, and had the highest and earliest queen and colony mortality ( $\leq 1 \mathrm{~d}$ ).

Small clusters of nonresponsive (intoxicated) workers typically formed on elevated areas of the hives and nearby structures; clusters dissipated over 1-3 d and presumably died. Intoxicated workers never attempted to sting each other or hive operators, and routinely were manipulated without a veil or smoker. The small feeding surface of bait and extended time required for swarms to dissolve the bait delayed intoxication and enabled surviving bees of some swarms to abscond. Small swarms were observed absconding from some bait hives (450 ppm, 3; 300 ppm, 1), but the fate of missing queens and workers from other bait hives generally was not observed. On d 10, the $0 \mathrm{ppm}$ group (control) had 7 queenright colonies with 4-6 small combs $\left(<8000 \mathrm{~cm}^{2}\right)$ containing larvae, little pollen, and traces of nectar; one colony was queenless and broodless. 


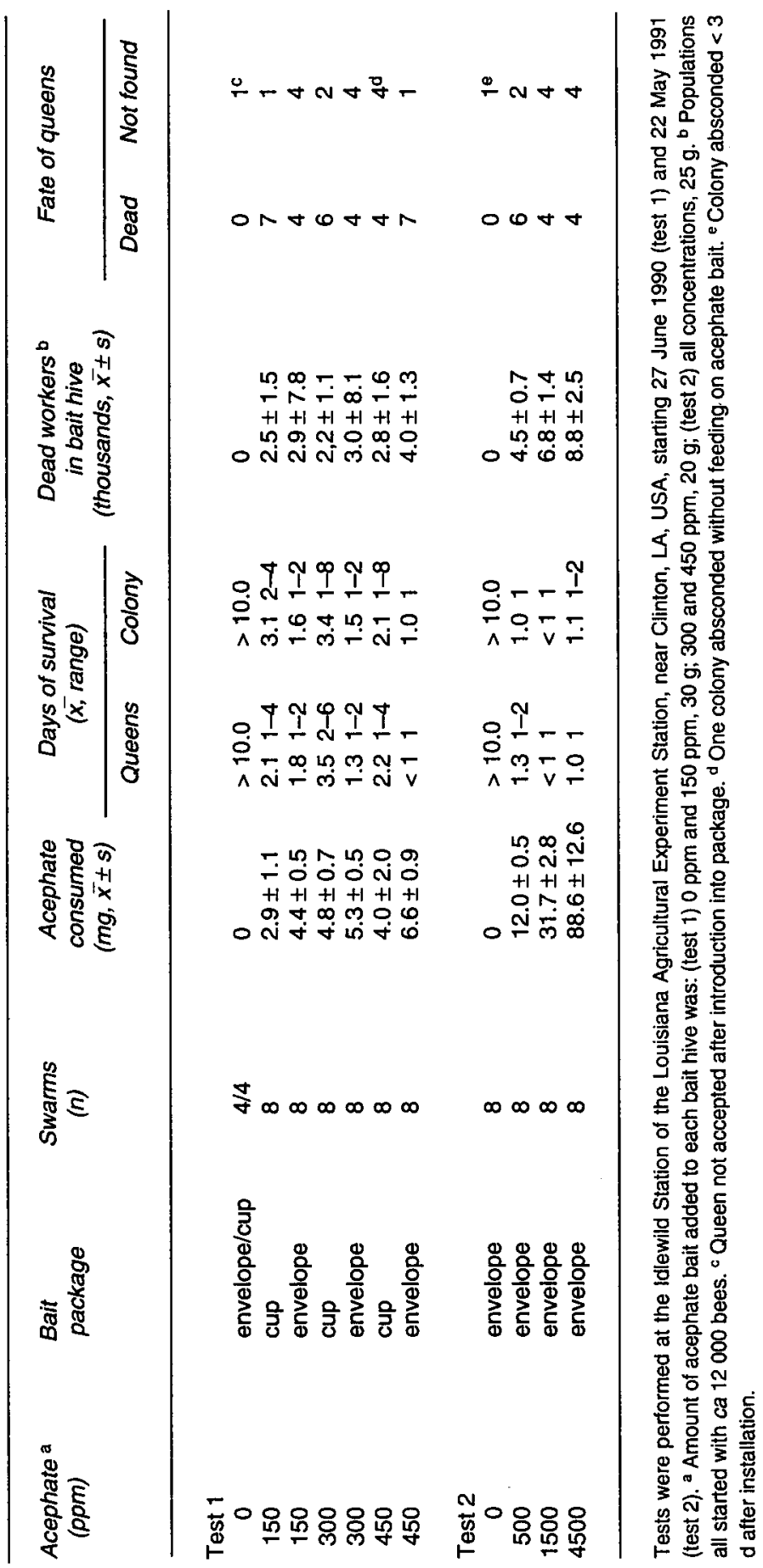




\section{Test 2}

All but 1 of 24 swarms given $500-4500$ ppm acephate bait were dead after feeding ca $24 \mathrm{~h}$ (< 500 live bees and no queen). The surviving swarm had ca 2000 live bees and a trace of bait at $24 \mathrm{~h}$, presumably as a result of delayed feeding. However, it was dead by $\mathrm{d} 2$ of inspection. Acephate concentrations ranging from $0-4500$ ppm significantly influenced amounts of acephate consumed by artificial swarms $(F=200.82$; $\mathrm{df}=2,21 ; P<0.0001$ ) and numbers of recovered dead workers $(F=11.33$; df $=2$, 21; $P=0.0005$ ) (table I). Acephate consumption was nearly 2,5 and 13.5 -fold that of swarms in test 1 that were given 450 ppm acephate bait in envelopes, whereas corresponding mortality (dead workers inside hives) increased only ca 1.2, 1.7 and 2.2-fold (table 1). The cause of the disproportionate mortality associated with increased acephate consumption was not determined. Total bee mortality inside the bait hives was ca $38 \%$ (500 ppm), 57\% (1 500 $\mathrm{ppm}$ ) and $73 \%$ (4 $500 \mathrm{ppm}$ ) of initial swarm populations. One control colony absconded between the $d 2$ and $d 3$ inspections, indicating poor foraging conditions in the test area. Symptoms of intoxication were the same as in test 1, except that no pesticideinduced absconding was observed.

The results collectively suggest that baits containing relatively low concentrations of acephate rapidly eliminate colonies while effecting low levels of environmental exposure from contaminated workers which leave the bait hive (estimated at $7.5 \mathrm{mg} \mathrm{ac}$ ephate/hive, assuming equal contaminaton bee). Colony mortality after 1-d exposure to $450-500$ ppm active ingredient (a i) in envelopes was $81 \%$ ( 7 of 8 in test $1 ; 6$ of 8 in test 2), based on recovery of both dead workers and queens from bait hives.

Ants occasionally fed on acephate bait or dead bees in bait hives or on the ground. Red imported fire ants (Solenopsis invicta Buren) sometimes were observed feeding on both acephate bait and dead bees, but in relatively small numbers. Feeding by other ant species was uncommon. Acephate may have repelled ants attracted to the treated baits or dead bees because none were seen feeding in large numbers or on consecutive days at a given bait hive. No nontarget honey bees from control or feral colonies were seen inspecting or foraging on either dead bees or on acephate baits left unprotected by weakened or dead swarms. Other larger nontarget animals (eg birds and rodents) may be excluded by covering the entrance hole of bait hives with hardware cloth (Sugden and Collins, 1990). Though acephate has a low mammalian toxicity (male rat oral $\mathrm{LD}_{50} \mathrm{ca}=945 \mathrm{mg} / \mathrm{kg}$ ) (Anonymous, 1988), acephate bait should include a strong repellent to avoid any possibility of its consumption by humans.

Field screening of 2 other toxicants was conducted in 1991. Artificial swarms in bait hives did not feed on similar fondant baits containing malathion ( $1600,3200,4800$ and $6400 \mathrm{ppm}$ ai malathion $25 \mathrm{WP} ; n=2$ ), although Witherell and Lewis (1986) reported a honey bait containing 3200 ppm malathion effectively killed a swarm and its queen. Avermectin $b_{1 a}$ (Avid ${ }^{\circledR} 0.15 \mathrm{EC}$ ) at $100 \mathrm{ppm}$ ai in sucrose-based bait $(n=2)$ was attractive to bees. Workers in rapidly dwindling artificial swarms continued to feed readily on Avid ${ }^{\circledR}$-treated bait (Williams, unpublished observations).

We consider that a refined version of the acephate-fondant bait may provide managers of Africanized honey bee survey and abatement programs an economical, rapid, low risk swarm destruction technique which substantially reduces labor requirements for operating large numbers of bait hives. The results suggest that fondant containing 450-500 ppm acephate best 
satisfies efficacy and safety requirements for such a bait. Additional field trials are needed to improve packaging materials and bait stability, and to evaluate the efficacy of the bait system against Africanized honey bee swarms.

\section{ACKNOWLEDGMENTS}

RT Daniel, DJ Pursifull, and DD Winfrey assisted with the fieid work. We thank FJ Peterson, Resident Director, for providing access to the Idlewild Station. This research was completed in cooperation with the Louisiana Agricultural Experiment Station.

Résumé - Appât à l'acéphate pour éliminer les essaims d'abeilles dans des pièges à essaim. De l'acéphate ajouté au sirop de saccharose utilisé comme appât ou en nourrissement direct provoque une intoxication létale aiguë ou chronique des colonies d'abeilles (Stoner et al, 1985; Williams et al, 1989; Danka et al, 1992). L'élimination automatique des essaims qui occupent les pièges à essaims augmentera grandement l'utilité de ces pièges dans les programmes de surveillance et d'élimination de l'abeille africanisée dans le Sud des États-Unis en empêchant l'établissement des colonies, la désertion, l'essaimage et les dangers de piqûre qui y sont associés. Des essaims artificiels constitués d'abeilles européennes et placés dans des pièges à essaims (environ 12000 abeilles/essaim) ont servi à établir l'efficacité d'appâts, constitués de saccharose et traités à l'acéphate, destinés à supprimer les essaims. Les pièges à essaims étaient des pots en pulpe de bois pressée d'une contenance de 31 I (Western Pulp Products Co, D1-29, Corvallis OR 97339). Les appâts ont été préparés avec du sucre de confiserie $(70,2 \%)$, du miel chauffé $(21,6 \%)$ et des quantités adéquates d'acéphate (Orthene ${ }^{\circledR} 75$ S) dissoutes dans de l'eau (8,2\%). En 1990 (test 1) 3 concentrations d'acéphate dans les appâts et 2 méthodes de conditionnement pour chacune des concentrations ont été comparées (56 essaims; 8 essaims/traitement, sauf 4/traitements dans 2 colonies témoins). La quantité d'appât à l'acéphate dans chaque piège à essaim était de : 0 et $150 \mathrm{ppm}$ pour $30 \mathrm{~g}$ d'appât et 300 et 450 ppm pour $20 \mathrm{~g}$ d'appât). Le conditionnement était constitué soit d'enveloppes de papier paraffiné $(H=12 \mathrm{~cm}, L=14 \mathrm{~cm})$, soit de coupelles en papier paraffiné de 95 $\mathrm{ml}$ couvertes. À toutes les concentrations, les essaims ayant reçu l'appât dans des enveloppes ont consommé plus d'acéphate et sont morts plus rapidement que ceux qui avaient reçu l'appât dans des coupelles. La mortalité des ouvrières dans les pièges à essaims a varié de $20 \%$ (150 ppm, coupelle) à $33 \%$ (450 ppm, envelop-

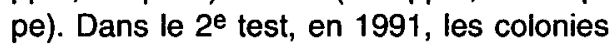
ayant reçu $25 \mathrm{~g}$ d'appât à l'acéphate $(500$, 1500 ou $4500 \mathrm{ppm}$ de matière active) dans des enveloppes ont consommé environ 12,32 et $89 \mathrm{mg}$ d'acéphate respectivement; le taux d'ouvrières mortes dans les pièges à essaims après $2 \mathrm{j}$ de traitement s'est respectivement élevé à $38 \%, 57 \%$ et $73 \%$ des populations d'origine. Un appât constitué de saccharose et renfermant 450 à 500 ppm d'acéphate répond en général aux critères d'efficacité et de sécurité pour son utilisation dans des pièges à essaims et peut réduire de façon substantielle les frais d'exploitation des vastes programmes de surveillance et de détection. Il est néanmoins nécessaire d'ajouter un répulsif à de tels appâts toxiques pour prévenir une éventuelle consommation par l'homme. D'autres tests sont nécessaires pour évaluer l'efficacité des appâts à l'acéphate visà-vis de l'abeille africanisée.

abeille africanisée / appât toxique / acéphate / piège à essaim 
Zusammenfassung - Acephate-Köder zur Vernichtung von Bienenschwärmen in Schwarmfallen. Acephate (Orthene ${ }^{\circledR}$ 75 S) in Zuckersyrup verursacht bei direkter Fütterung oder Verabreichung in einem Köder die chronische oder akute Vergiftung von Bienenvölkern (Stoner et al, 1985; Williams et al, 1989; Danka et al, 1992).

Die automatische Vernichtung von Schwärmen in Schwarmfallen wird den Effekt der Fallen in den Programmen zur Überwachung und Ausaschaltung afrikanisierter Bienen in den südlichen Vereinigten Staaten erhöhen, indem sie die Entwicklung von Völkern, Schwärmen und die damit verbundenen Zwischenfälle durch Stiche verhindern.

Kunstschwärme von Bienen europäischer Abstammung (etwa 12000 Bienen) in Schwarmfallen wurden benutzt, um die Wirksamkeit von mit Acephate versetzten Ködern auf Zuckerbasis zu ihrer Vernichtung zu prüfen. Als Schwarmfallen wurden Bienentöpfe aus gepreßtem Zellstoff von 31 I Inhalt verwendet (Western Pulp Products Co, Dl-29, Corvallis, OR 97339). Die Köder wurden aus Konditor-Zucker (70.2\%), erhitztem Honig (21.6\%) und der erforderlichen Menge von Acephate (Orthene $\left.{ }^{\circledR} 75 \mathrm{~S}\right)$, gelöst in Wasser $(8.2 \%)$, hergestellt. Im Jahre 1990 wurden 3 Acephate-Konzentrationen in den Ködern sowie zwei Verabreichungsmethoden/ Konzentration (56 Schwärme; $n=8$ je Versuch, ausgenommen die 2 Kontrollen mit nur 4 je Versuch) miteinander verglichen. Die Menge des Acephateköders in den Schwarmfallen betrug 0 \& $150 \mathrm{ppm}$, $30 \mathrm{~g} ; 300$ \& 450 ppm, $20 \mathrm{~g}$. Die Verpackung bestand entweder aus Umschlägen aus Wachspapier $(12 \mathrm{~cm}$ hoch, $14 \mathrm{~cm}$ breit) oder aus bedeckten Bechern aus Wachspapier zu $95 \mathrm{ml}$. Bei jeder Konzentration verzehrten die Bienen in den Fallen mit Umschlägen mehr von dem
Köder und sie starben früher als die Bienen mit dem Köder in Bechern. Die Sterblichkeit der Arbeiterinnen im Inneren der Fallen schwankte zwischen 20\% (150 ppm, Becher) und $33 \%$ (450 ppm, Umschläge).

Bei Versuch 2 (1991), bei dem den Schwärmen $25 \mathrm{~g}$ Acephateköder (500, 1500 , oder 4500 ppm der aktiven Substanz) in Umschlägen verabreicht wurden, verzehrten die Bienen je etwa 12, 32 und $89 \mathrm{mg}$ Acephate und der Anteil toter Arbeiterinnen zwei Tage nach der Behandlung betrug je $38 \%, 57 \%$ und $73 \%$ der ursprünglichen Population.

Köder auf Zuckerbasis mit 450-500 ppm Acephate entsprechen im allgemeinen den Anforderungen an Wirksamkeit und Sicherheit für die Anwendung in Schwarmfallen, und sie können die laufenden Kosten eines umfangreichen Überwachungs-und Auffindungsprogramms wesentlich senken. Für einen derart toxischen Köder muß jedoch noch ein Repellent hinzugefügt werden, um einen möglichen Verzehr durch Menschen zu verhindern. Zusätzliche Versuche sind erforderlich, um die Wirksamkeit solcher Acephatetköder im Einsatz gegen afrikanisierte Bienen zu prüfen.

\section{Afrikanisierte Bienen / Acephateköder / Schwarmfallen}

\section{REFERENCES}

Anonymous (1988) Farm Chemicals Handbook. Meister Publishing $\mathrm{Co}$, Willoughby, $\mathrm{OH}$

Danka RG, Williams JL, Sugden EA, Rivera RA (1992) Field tests of an acephate baiting system designed for eradicating undesirable honey bees (Hymenoptera: Apidae). J Econ Entomol 85, 1104-1111

Fierro MM, Munoz MJ, Lopez A, Sumuano $X$, Salcedo H, Roblero G (1988) Detection and 
control of the Africanized bee in coastal Chiapas, Mexico. Am Bee J 128, 272-275

Gary NE (1971) Possible approaches to controlling the African honey bee. Am Bee J 111, 426-429

Michener CD (1975) The Brazilian bee problem. Annu Rev Entomol 20, 399-416

Oertel E (1971) Reviving an apiary. Glean Bee Cult 99, 678-696

Rubink WL, Wilson WT, Resendez JJ, Maki DL (1990) Pre-Africanized Apis mellifera (Hymenoptera: Apidae) swarming dynamics in northeastern Mexico and southern Texas. $J$ Kans Entomol Soc 63, 286-295

SAS Institute (1985) SAS/STAT Users Guide. Version 5. SAS Institute, Cary, NC

Schmidt JO, Thoenes SC (1987) Swarms traps for survey and control of Africanized honey bees. Bull Entomol Soc Am 33, 155-158

Schmidt JO, Thoenes SC (1990) The efficiency of swarm traps: what percent of swarms are captured and at what distance from the hive. Proc 5th Am Bee Res Conf, Oct 1-2, 1990, Tucson, AZ. Am Bee J 130, 811-812

Schmidt JO, Thoenes SC, Hurley R (1989) Swarm traps. Am Bee J 129, 468-471

Stoner A, Wilson WT, Harvey J (1985) Acephate (Orthene®): effects on honey bee queen, brood and worker survival. Am Bee $J$ 125, 448-450

Sugden EA, Collins AL (1990) Burglar bars exclude vertebrates, minimize bait hive loss. Proc 5th Am Bee Res Conf, Oct 1-2, 1990; Tucson, AZ. Am Bee J 130, 814-815

Williams JL, Danka RG, Rinderer TE (1989) Baiting system for selective abatement of undesirable honey bees. Apidologie 20, 175-179

Witherell PC, Lewis JE (1986) Studies on the effectiveness of bait hives and lures to attract honey bee swarms - a survey tool for use in Africanized honey bee eradication programs. Am Bee J 126, 353-361 